\title{
Climate Change Effect on Coffee Yield and Quality: A Review
}

\author{
Afework Legesse* \\ Ethiopian Institute of Agricultural Research, Jimma Agricultural Research Center, P. O. Box 192, Jimma, Ethiopia. \\ *Corresponding Authors: Afework Legesse, Ethiopian Institute of Agricultural Research, Jimma Agricultural \\ Research Center, P. O. Box 192, Jimma, Ethiopia.
}

\begin{abstract}
Climate changes are alarming the world by hampering agriculture and its products. Coffee production is highly dependent on a regular sequence of weather events. Alteration in precipitation patterns, temperature, storms, strong winds and other extreme weather events directly impact coffee quality and productivity levels. In this paper, the production, growth requirements of coffee, climate change factors and the impact of climate change on coffee yields and quality were assessed in detail. Potential solutions for minimizing the influence of climate change on coffee productivity and quality are also discussed.
\end{abstract}

Keywords: Adaptation, Climate Change, coffee quality, coffee yield, Mitigation.

\section{INTRODUCTION}

Coffee is one of the most widely drunk beverages in the world, and is a very important source of foreign exchange income for many countries. More than 125 million people in the coffee growing areas worldwide derive their income directly or indirectly from its products (Lashermes et al., 2011; Mishra and Slater, 2012). It ranks second after oil in international trade and has created several million jobs in the producer and consumer countries where more than nine million tons of green beans are produced annually (ICO, 2016). In the world, Brazil is the leading coffee producer and exporter country followed by Vietnam, Colombia, Indonesia and Ethiopia (ICO, 2016). The genus Coffea comprises nearly 124 well identified species; however, Coffea arabica L. and Coffea canephora P. are the two commercially important species (Davis et al., 2006; Gray et al., 2013). Predominately, Arabica coffee represents $70 \%$ of global coffee production and Caniphora (Robusta) represents about 30\% (Damatta and Ramalho, 2006; Davis et al., 2012). The production and productive of both species are largely dependent on the climate for attain high yields and quality (Killeen and Harper, 2016).

The effect of climate variation on natural systems has begun as one of the most critical issues of humankind (Jaramillo et al., 2009). Many finding proof that weather alteration is hastening at ample quicker stride than earlier that leading to irreversible changes in major earth systems and ecosystems (ITC, 2010). Important factors that play a role for climate change are, rising fossil fuel burning and land use changes are continuing to emit, and increasing quantities of greenhouse gases into the Earth's atmosphere. The rising greenhouse gases [carbon dioxide $(\mathrm{CO} 2)$, methane $(\mathrm{CH} 4)$ and nitrogen dioxide (N2O)] in the atmosphere can increase the amount of heat from the sun withheld in the Earth's atmosphere, that would normally be radiated back into space (Vergara, 2014). Carbon dioxide (CO2) and methane $(\mathrm{CH} 4)$ are the most greenhouse gases that influence global climate through emissions (Masters et al., 2009). Climate change is transforming ecosystems on an extraordinary scale, at an extraordinary pace. The main characteristics of climate change are increases in average global temperature (global warming); changes in cloud cover and precipitation particularly over land; melting of ice caps and glaciers and reduced snow cover; and raise in ocean temperatures and ocean acidity due to seawater absorbing heat and carbon dioxide from the atmosphere (IEH, 2012).

Changing climatic conditions and rising global temperatures pose one of the most significant threats to world coffee production. According to Killeen and Harper (2016) both the productivity and quality of Arabica and Robusta coffee largely depend on the climate suitability, especially the precipitation and air 
temperature. While climate change has the potential to influence the plant yield directly by heat and water stresses, it can also have an indirect impact by affecting the fertilizer supply, pathogens, and pests (Mo et al., 2017). The majority of researchers agree that global warming is irreversible over a short period and requires global policy change and sustainable agricultural practices for a long period to mitigate and reverse the environmental damage. The primary objective of this review is to assess the influence of climate change on the yields and quality of coffee production.

\section{Global COFFEe PROduCTion}

Over the past 50 years, both production and consumption of coffee have risen considerably (FAO, 2015). Now over 70 countries produce coffee, and over 50 percent comes from just three countries Brazil, Veitnam and Colombia (Fig 2). The dynamics of world coffee production are generally characterized by considerable instability, with a large crop in one year frequently followed by a smaller crop in the next (ICO, 2014). The average growth rate since 1963 was $2.4 \%$, with $2.8 \%$ annual growth in the marketcontrolled period, and 2\% since 1990 (Fig 1). In crop year 2012/13, world coffee production reached 145.1 million bags, the largest on record. With the exception of Africa, all coffee-growing regions recorded a steady growth in their production over the time period (ICO, 2014). According to the USDA, world coffee production for the crop year 2019/20 is forecasted at 5.4 million bags (60 kilograms) lower than the previous year to 169.1 million, due primarily to Brazil's Arabica trees entering the off year of the biennial production cycle. With global consumption forecast at a record 167.9 million bags, ending inventories are expected to retreat 2.8 million bags to 33.5 million. However, due to local consumption, export volume does not represent total production volume.

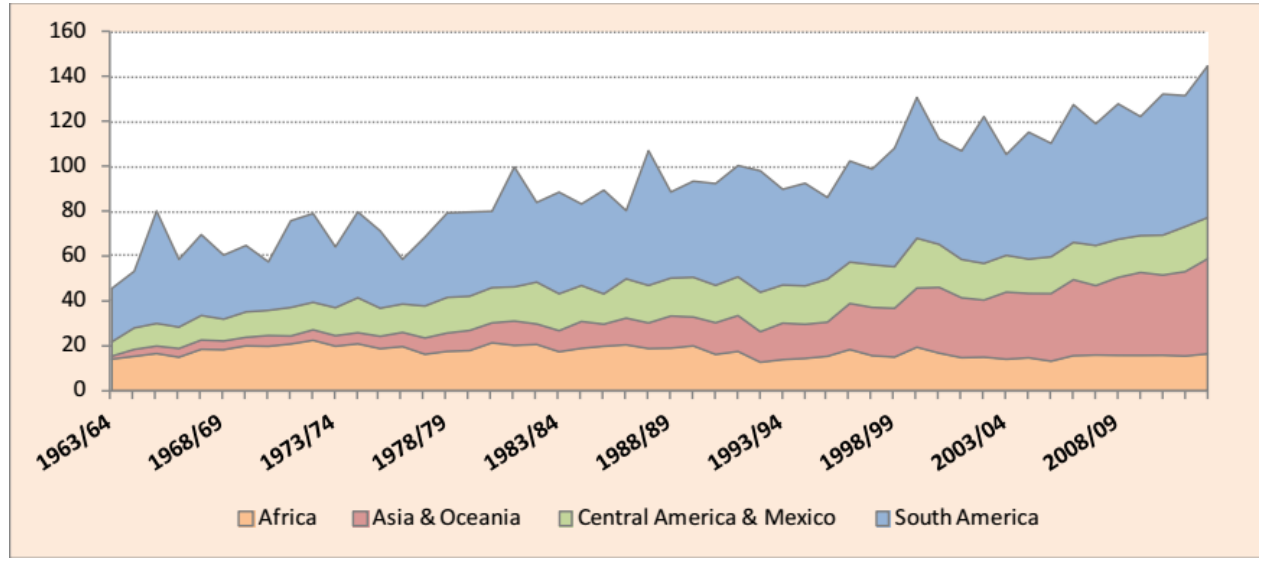

Figure1. World coffee production by region (1963/64 - 2012/13)

Source: International coffee organization

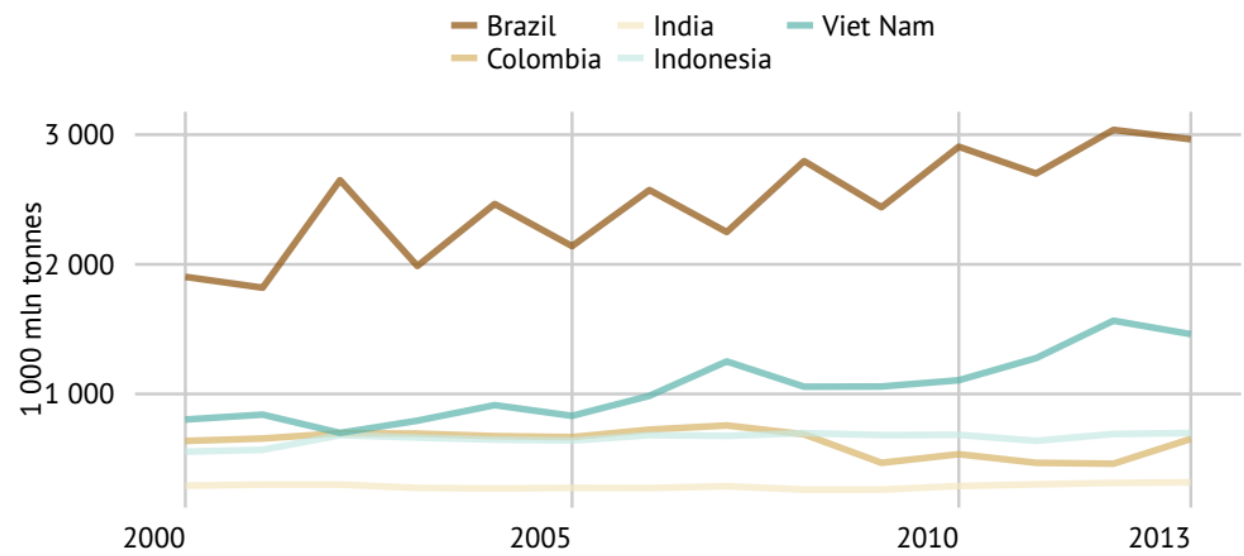

Figure2. Production quantities of top 5 coffee producers 2000 - 2013

Source: $F A O, 2015$

International Journal of Forestry and Horticulture (IJFH) 
Over the past 25 years, since the collapse of the quota system policed by the ICO, global coffee production has been increasing by a mean of 144,400 t yr-1 (Figure 3, left). Of the leading 25 coffee countries over the past 25 years, only 9 (Brazil, Ethiopia, Honduras, Indonesia, India, Malaysia, Nicaragua, Peru and Vietnam) have shown significant growth according to USDA figures (Baker, 2015).

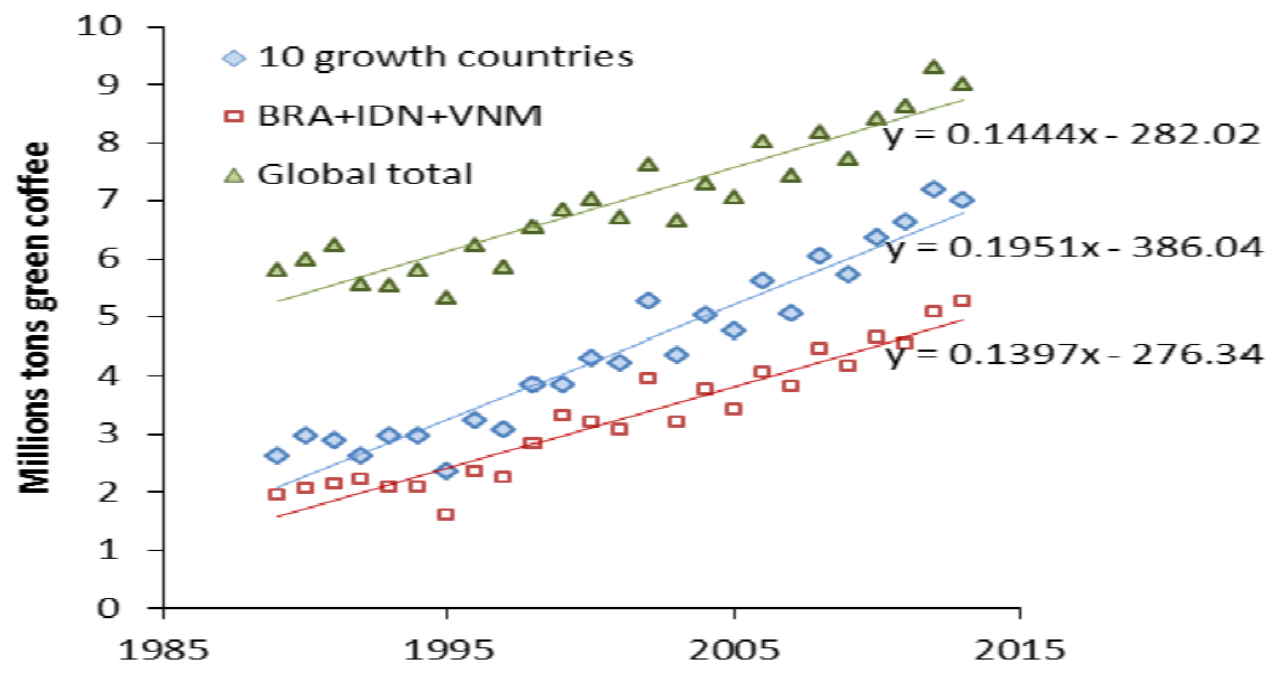

Figure3. Left: world coffee production of all countries (triangles), ten growth countries (diamonds) and Brazil+Indonesia+Vietnam (squares) since 1989.

\section{ECOLOGY OF COFFEE}

An elevation greater than 1000 meter above sea level (masl) is required for Arabica coffee. In Low elevation it does not possess the quality required by the world market (Mangal, 2007). Ideal rainfall for Arabica coffee is in the range of 1200 to $1500 \mathrm{~mm}$ per year. Both the total amount and the distribution pattern are important. Rain should to be uniformly distributed over 7-9 months of the year. Coffee needs a dry, stress period with little or no rain to induce a uniform flowering. Without a stress period, flowering may extend over many months making harvesting more difficult (Mangal, 2007). However, the process of photosynthesis becomes limited when prolonged water stress occurs, due to closing of the stomata and reduction in other physiological activities of the plant (Camargo, 2009). The optimum average temperature ranges between 15 and $24^{\circ} \mathrm{C}$, though it can tolerate temperatures much below or above these limits for short periods (Wrigley, 1988).

Robusta is much less adaptable to lower temperatures than Arabica. Both leaves and fruits do not withstand temperatures below $6^{\circ} \mathrm{C}$ or long periods at $15^{\circ} \mathrm{C}$. As altitude relates to temperature, Robusta coffee can be grown between sea level and $800 \mathrm{~m}$, whereas Arabica coffee grows better at higher altitudes and it grows better in areas with annual mean temperature among $22^{\circ} \mathrm{C}$ to $26^{\circ} \mathrm{C}$ (Camargo, 2009).

\section{Climate Change}

Climate change refers to a statistically significant variation in either the mean state of the climate or in its variability, persisting for an extended period (typically decades or longer). Global climate change is a change in the long-term weather patterns that characterize the regions of the world (Vijaya et. al., 2011). Ever since the Industrial Revolution began about 150 years ago, man-made activities have added significant quantities of greenhouse gases (GHGs) to the atmosphere. According to the Third Assessment Report on climate change 2001 of the Inter-Governmental Panel on climate change, the atmospheric concentrations of carbon dioxide, methane, and nitrous oxide have grown by about $31 \%, 151 \%$ and $17 \%$, respectively, between 1750 and 2000. Furthermore, climate change (drought, flood, high temperature, storm etc.) events are increased dramatically as reported by Food and Agriculture Organization (FAO) and as shown in Figure 1. An increase in the levels of GHGs could lead to greater warming, which, in turn, could have an impact on the world's climate, leading to the phenomenon known as climate change. The increasing trend of $\mathrm{CO} 2$ emissions and sea level and global surface temperature is shown in Figs. 4 $\& 5$ respectively. 


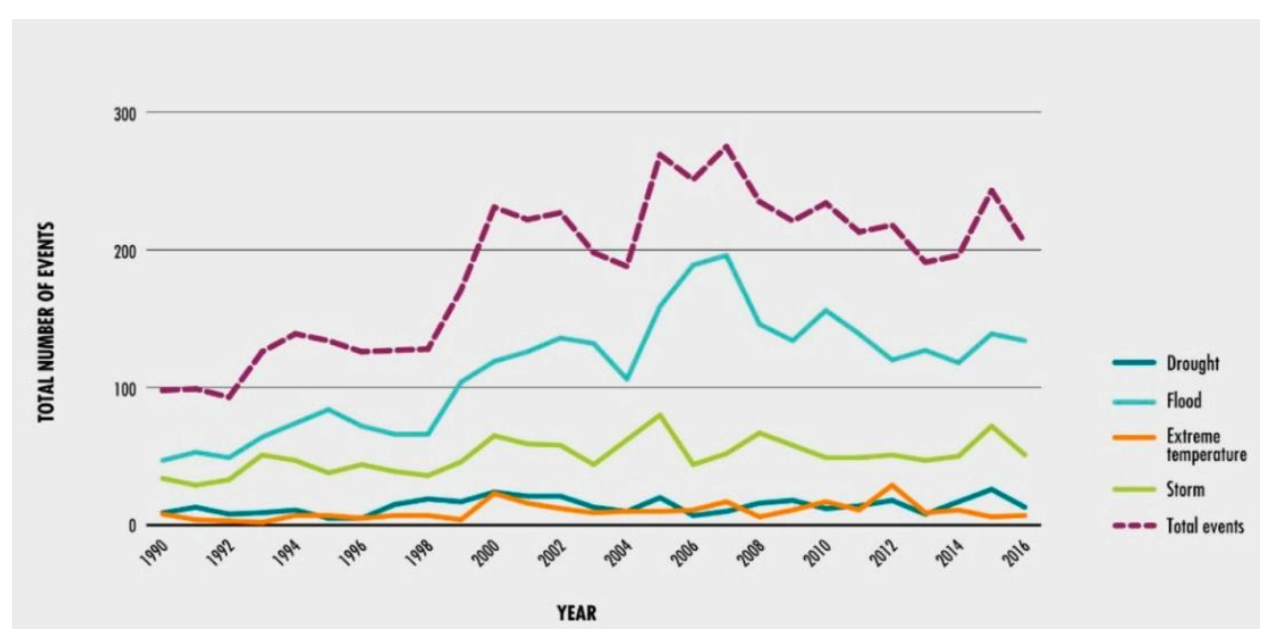

Figure4. Increasing number of extreme climate-related events occurred during 1990-2016

Source: Food and Agriculture Organization (FAO) based on data from Emergency Events Database (EM-DAT)

\subsection{Carbon Dioxide Emission}

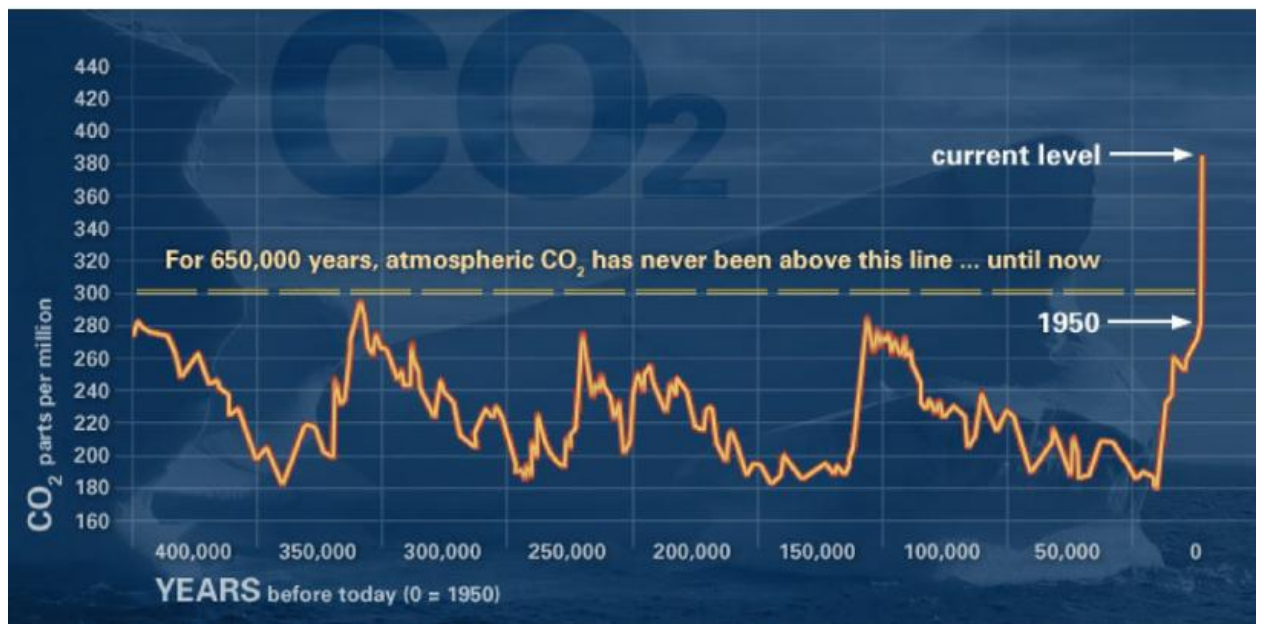

Figure5. CO2 (ppm) trend over years. $\quad$ Source: NASA satellite data

\subsection{Global Surface Temperature}

Global land ocean temperature index

Source: NASAGGISS. This research is broadly consistent with similar constructions prepared by the Climatic Research Unit and the National Atmospheric and Oceanic Administration Credit: NASA/GISS

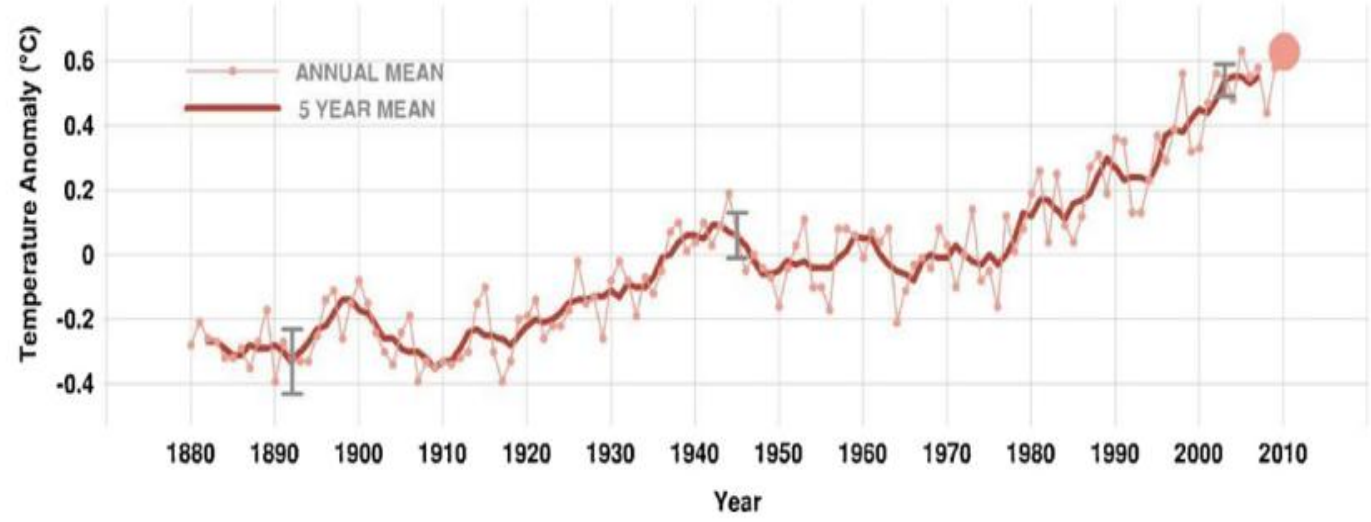

Figure6. Global temperature variation. Source: NASA satellite data 


\section{IMPACT OF Climate Change ON COFFEE Yield}

Physiological processes can be influenced by increases in temperature above $30^{\circ} \mathrm{C}$, especially if the air is dry. In general, Arabica coffee does best at higher altitudes and is often grown in hilly areas (Cambrony, 1992; Coste, 1992; Wrigley, 1988). However, coffee growth and fruiting can also be easily affected by physiological problems due to temperature drops, particularly with increased altitudes. Also water stress affects the physiological activity of the Arabica plant causing a reduction in photosynthesis (ICC, 2009).

Studies indicated that at temperatures above $24^{\circ} \mathrm{C}$, the net photosynthesis of coffee decreases markedly, approaching zero at $34^{\circ} \mathrm{C}$, hinder the development and ripening of cherries and when continued, it could result in reduced growth or even in yellowing and loss of leaves (ICC, 2009; Magrach and Ghazoul, 2015).

Water availability has also been found to affect the maintenance of maximum photosynthetic rates, high fruit set levels, and fruit size. Coffee phenology is therefore vulnerable to both the quantity of precipitation and the timing of precipitation events (Magrach and Ghazoul, 2015).

Climate variation is the most favorable for increase of coffee pest disease; the loss estimate globally is $13 \%$ of yield reduction (Agegnehu et al., 2015). Major disease that occurred because of climate variation during coffee growing will increase pest and disease prevalence, expanding the altitudinal range in which the fungal disease coffee rust and the coffee berry borer can survive (Läderach et al., 2010). The most significant coffee pests which becomes series and damaging with climate change leaf rust (Hemileia vastatrix) and the coffee berry borer (Hypothenemus hampei) (CTA, 2014). Coffee Leaf Rust which is favored by high temperatures becomes more series disease and affects coffee in high altitude areas (Lin et al., 2008). Coffee berry disease (CBD) is also favored by high precipitation and low temperature which becomes more severe than ever; change in temperature will affect insect pest dynamics, such as minor pests may become major pests; e.g. thrips (Lin et al., 2008).

The other challenge of climate change is the loss of suitable land for coffea arabica cultivation. The rising of temperature render to a certain production areas less suitable or even completely unsuitable for coffee growing, production may have to shift (Jamillo et al., 2011). Davis et al. (2012) predict that climate change will lead to a 65 percent reduction in suitable land for Arabica coffee growth. This is their bestcase scenario prediction. At worst, they found that 100 percent of suitable land for Arabica coffee production will disappear due to climate change by the year 2080. They determined a negative trend between the increase in global temperatures and the growth of Arabica coffee (Davis et al., 2012). A shift in climate and agricultural zones towards the higher altitudes, changes in production, patterns due to higher temperature, changing precipitation patterns, increased vulnerability of the landless and the poor (Lin et al., 2008). Yield declines of Coffee are virtually certain in a warming world because it is a montane species, not adapted to high temperatures (CCAFS, 2016).

\section{Impact of Climate Change on Coffee Quality}

The potential yield and quality of coffee is determined by both temperature and rainfall condition since both ability to interfere with the phonological growth of the crop (Haggar and Schepp, 2011). These impacts include, for example, disrupted flowering cycles and prolonged drought periods, which ultimate result in reduced coffee quantity and quality (Masters et al., 2009). According to Killeen and Harper (2016) both the productivity and quality of Arabica and Robusta coffee largely depend on the climate suitability, especially the precipitation and air temperature. However, the Arabica coffee is more sensitive to climate variation, specifically during blossoming and fructification stage (Haggar and Schepp, 2011). High elevation improves the quality of the bean and potential cup quality due to delay in ripening brought about by cooler weather associated with higher altitudes, and the inherent characteristics of acidity, aroma and bold bean can develop fully (Mangal, 2007). Above $23^{\circ} \mathrm{C}$, fruit development and ripening are accelerated, leading to loss of quality; below $18^{\circ} \mathrm{C}$, growth is depressed (Mofatto, 2016).

Incidences of pests and diseases result in decrease of coffee quality and viability of the product. Jaramillo et al. (2011) estimated that climate change would worsen the pest prevalence including that of the berry borer, contributing to the decrease of coffee fruit and bean quality. In Africa, research shows the insect probably originated as a predator to Coffea canephora, a lesser-used coffee plant that grows at lower 
altitudes and warmer temperatures than Coffea arabica (Jaramillo et al., 2011). Jaramillo et al. (2009) found that the population growth of $H$. hampei is directly and exponentially related to increases in temperatures. As temperatures rise, generations of the insect multiply. A study performed by Jaramillo et al. (2009) determined that a 1 to 2 degree Celsius increase in temperature would cause the $H$. hampei to develop faster; this would lead to more generations per fruiting season. They found that increases of over 2 degrees Celsius would force the H. hampei to migrate to higher altitudes. This explains the bugs' shift from lower elevation where Coffea canephora grows to the higher altitudes of Coffea arabica.

Increased drought and sunshine can induce the premature ripening of the beans, with sufficient quality loss as well as the yield (Mofatto, 2016). Water availability has also been found to affect the maintenance of maximum photosynthetic rates, high fruit set levels, and fruit size. Coffee phenology is therefore vulnerable to both the quantity of precipitation and the timing of precipitation events (Magrach and Ghazoul, 2015).

\section{Potential Strategies to Increase Coffee Production}

\subsection{Climate Change Mitigation}

Mitigation of global warming involves taking actions to reduce greenhouse gas emissions to enhance sinks aimed at reducing the extent of global warming which is important (International Coffee Council, 2009). Climate change mitigation strategies which include interventions to reduce the sources or enhanced the sinks of greenhouse gases have a marked management component aiming at conservation of natural resources such as improved fertilizer use, use of water harvesting and conservation techniques. These strategies are equally consistent with the concept of sustainability (Bento and Camargo, 2009).

Mitigation can be divided into two concepts: Reducing the contribution of coffee production to greenhouse gas emissions, this is primarily a function of the carbon footprint of coffee production and Sequestration of carbon in the shade trees or forest areas of the coffee farms, currently the conservation of existing trees has no process for recognition but planting of new trees could be considered as mitigating other emissions (Haggar and Schepp, 2012). Carbon sequestration is an important technology for the maintenance of optimum $\mathrm{CO} 2$ level in the atmosphere, which in turn results in the climate change mitigation (Vijaya et al., 2011). Studies of carbon footprints from coffee production indicate that on-farm emissions, and in particular nitrogen fertilization account for about $40 \%$ of the carbon footprint of the whole coffee chain (PCF, 2008).

\subsection{Adaptation Strategies}

Adaptation strategies include initiatives and measures to reduce the vulnerability of agro-ecosystems to projected climate change, such as changing varieties, altering the timing or location cropping activities, improving the effectiveness of pest, disease and weed management practices, making better use of seasonal climate forecast etc (Bento and Camargo, 2009). Measures to adapt coffee cultivation to climate change also contribute to reducing $\mathrm{CO} 2$. Other environmental benefits include enhanced water storage, the regulation of local temperatures, and biodiversity conservation (Lossau, 2010). Adaptation strategies may range from a change in crop cultivars to accommodate drought or shifts in temperature to extreme measures such as a total change in land use away from agriculture production (Smith et al., 2007). Good management practices that reduce soil erosion (e.g. cover crops and contour bunds) and increase water retention (mulching, shade) will further help farmers adapt to climate change and retain the more fertile topsoil (Deressa et al., 2009; Jassogne et al., 2013).

Different scholars seem to agree that the best way to preserve Arabica coffee is through the use of shade trees (Jaramillo et al., 2009). Shade trees planted near coffee plants have the ability to block out the sun's impact on the plants. They create lower temperature, reduce up to $4{ }^{\circ} \mathrm{C}$ better suited for Arabica coffee plants.

Improving new cultivars resistant to pests and diseases, more productive, well adapted to the local climatic and soil conditions, and have acceptable and desired quality for the market is very important (Enomoto, 2011). Ethiopia has a unique genetic diversity of cultivated, semi-wild and wild Arabica varieties with different types of disease resistance environmental adaptations and quality characteristics for future breeding coffee varieties opportunity that are adapted to the changed climate (Lossau, 2010). 


\subsection{Synergies in Adaptation and Mitigation}

The potential for developing synergies between climate change mitigation and adaptation has become a recent focus of both climate research and policy. There are also increasing calls for research to define the optimal mix of mitigation and adaptation (Klein et al., 2005).

By focusing mitigation objectives in key cost-effective sectors, adaptation needs in key food producing activities could be chosen to provide mitigation at the same time. Indeed, several adaptation activities leading to increased systems resilience and improved rural incomes may still have significant mitigation value, resulting in no-regrets, win-win situations. For example, this would include the entire set of good practices that lead to improved soil and water resource conservation (Tubiello, 2012).

\section{CONClusion}

This review summarizes the production, growing requirements of coffee, and influences of climate change on the yields and quality of coffee around the world. Climate mitigation and adaptation techniques were presented as solutions to address these issues and challenges caused by global warming. The fluctuation of climate in the coffee growing area resulted in reduction in the yield and quality, increasing the outbreak of pest disease, increasing cost of production and reduced area of production. The consequence of the problem may make the coffee sector to have negative impact on the producers and consumers. Comprehensive application of all adaptation practice ensures high quality and sustainable production of coffee and also maintain sustainable ecosystem. Generally, further research will be focused on discovering climate change adaptation strategies feasible for smallholder farmers for practically implement.

\section{REFERENCES}

[1] Agegnehu E, Thakur A, Mulualem T, 2015. Potential Impact of Climate Change on Dynamics of Coffee Berry Borer (Hypothenemus hampi Ferrari) in Ethiopia. Open Access Library J. 2(01):1.

[2] Camargo, Marcelo B. P., 2009. The Impact of Climate Variability in Coffee Crop.

[3] Cambrony H.R, 1992. Coffee growing. CTA/the Macmillan Press Ltd., New York.

[4] CCAFS (Climate change agriculture and food security) (2016). Climate change adaptation in agriculture: practices and technologies Dinesh D, Vermeulen S (Ed.) Messages to the SBSTA 44 agriculture workshops.

[5] Coste R, 1992. Coffee: The plant and the product. Macmillian, London.

[6] CTA (Technical Centre for Agricultural and Rural Cooperation), 2014. Climate-smart agriculture in Africa Higman S, Kingdom U (ed.), Anibal, Mozambique, pp. 34-40.

[7] Damatta FM, Ramalho JDC, 2006. Impacts of drought and temperature stress on cofeee physiology and production: a review. Braz. J. Plant Physiol. 18:55-81.

[8] Davis AP, Gole TW, Baena S, Moat J, 2012. The impact of climate change on indigenous arabica coffee (Coffea arabica): predicting future trends and identifying priorities. PLoS One 7(11):e47981.

[9] Davis, AP, Govaerts, R, Bridson, DM and Stoffelen P, 2006. An annotated taxonomic conspectus of the genus Coffea (Rubiaceae). Botanical Journal of the Linnean Society, 152 (4), pp. 465-512.

[10] Deressa TT, Hassan RM, Ringler C, Alemu T, Yesuf M, 2009. Determinants of farmers' choice of adaptation methods to climate change in the Nile Basin of Ethiopia. Global environmental change 19(2):248-255.

[11] Enomoto R, 2011. Climate-friendly and Productive farming Guide for Coffee smallholders in Africa.

[12] FAO, 2015. Food and agriculture organization of United Nations. Climate Change and the 2015 International Year of Soils. Publications.

[13] Gray Q, Tefera A, Tefera T, 2013. Ethiopia: Coffee annual report. GAIN Report No. ET-1302, GAIN Report Assessment of Commodity and Trade by USDA, USA.

[14] Haggar J, Schepp K, 2011. Coffee and climate change. Desk study: impacts of climate change in four pilot countries of the coffee and climate initiative. Hamburg: Coffee and Climate.

[15] ICC (International Coffee Council), 2009. Climate change and coffee, 103rd Session 23 - 25 September 2009 London, England.

[16] IEH (Instituto de Estudios del Hambre), 2012. Analysis of climate change impacts on coffee coca and basic grains value chains in Northern Hondurans. 
[17] International Coffee Organization (ICO), 2014. Fourth International World coffee Conference.112th session from 7-14 march 14. London, United Kingdom. Available on: http:// dev.ico.org/ documents/ cy2013-14/wccEthiopia- presentation.

[18] International coffee organization (ICO), 2016. Sustainability of the coffee sector in Africa International Coffee Council 117th session of the Council held in London, United Kingdom.

[19] International Trade Centre (ITC), 2010. Climate Change and the Coffee Industry Geneva: ITC, vi, 28 pages (Technical paper).

[20] IPCC, 2012. Glossary of terms. In: Managing the Risks of Extreme Events and Disasters to Advance Climate Change Adaptation [Field CBV, Barros TF, Stocker D, Qin DJ, Dokken KL, Ebi MD, Mastrandrea KJ, Mach GK, Plattner SK, Allen M, Tignor, PM Midgley (eds.)]. A Special Report of Working Groups I and II of the Intergovernmental Panel on Climate Change (IPCC). Cambridge University Press, Cambridge, UK, and New York, NY, USA, 555-564.

[21] Jaramillo J, Muchugu E, Vega FE, Davis A, Borgemeister C, 2011. Some Like It Hot: The Influence and Implications of Climate Change on Coffee Berry Borer (Hypothenemus hampei) and Coffee Production in East Africa. PLoS ONE 6 (9): e24528. doi: 10.1371/journal.pone.0024528.

[22] Jaramillo J, Olaye AC, Kamonjo C, Jaramillo A, Vega FE, Poehling M, Borgemeister C, 2009. Thermal tolerance of the coffee berry borer Hypothenemus hampei: Predictions of climate change impact on a tropical insect. PLoS ONE 4 (8): e6487. DOI: 10.1371/journal.pone.0006487.

[23] Jassogne L, Läderach P , Asten VP, 2013. The Impact of Climate Change on Coffee in Uganda: Lessons from a case study in the Rwenzori Mountains. Oxfam Policy and Practice: Climate Change and Resilience 9(1):5166.

[24] Jeremy Haggar and Kathleen Schepp, 2012. Coffee and Climate Change Impacts and options for adaption in Brazil, Guatemala, Tanzania and Vietnam. NRI Working Paper Series: Climate Change, Agriculture and Natural Resources No. 4.

[25] Killeen JT, Harper G, 2016. Coffee in the 21st century. Will Climate Change and Increased Demand Lead to New Deforestation? Conservation international.

[26] Klein RJT, Schipper ELF, Suraj Dessaid, 2005. Integration mitigation and adaptation into climate and development policy: three research questions. Environmental Science \& Policy 8(6):579-88.

[27] Läderach P, Haggar J, Lau C, Eitzinger A, Ovalle O, Baca M , Jarvis A , Lundy M, 2010. Mesoamerican coffee: Building a climate change adaptation strategy. CIAT Policy Brief no. 2.Centro International de Agricultura Tropical (CIAT), Cali, Colombia.

[28] Lashermes, P., M.C. Combes, C.Ansaldi, E. Gichuru and S. Noir, 2011. Analysis of alien introgression in coffee tree (Coffe aarabica L.). Molecular breeding, 27(2): 223-232.

[29] Lin BB, Perfecto I, Vandermeer J, 2008. Synergies between Agricultural Intensification and Climate Change Could Create Surprising Vulnerabilities for Crops, J. American Ins. Bio. Sci., 58 (9): 847-854.

[30] Lossau VA, 2010. Agro biodiversity and adapting to climate change: The example of coffee. Agriculture, Fisheries and Food.

[31] Magrach A, Ghazoul J, 2015. Climate and Pest-Driven Geographic Shifts in Global Coffee Production: Implications for Forest Cover, Biodiversity and Carbon Storage. PLoS ONE 10 (7): 1371.

[32] Mangal, S.K., 2007. Coffee: Planting, Production and Processing. Gene-Tech Books.

[33] Marcelo Bento and Paes De Camargo, 2009. The Impact of Climatic Variability and Climate Change on Arabic Coffee Crop in Brazil. Bragantia, Campinas, 69 (1), p.239-247

[34] Masters G, Baker P, Flood J, 2009. Climate Change and Agricultural Commodities. CABI Position Paper.

[35] Mishra, M. K., and A. Slater, 2012. Recent Advances in the Genetic Transformation of Coffee, Review Article. Biotechnology Research International.

[36] Mo XG, Hu S, Lin ZH, Liu SX, Xia J,2017. Impacts of climate change on agricultural water resources and adaptation on the north China plain. Adv. Clim. Chang. Res. 8, 93-98.

[37] Mofatto LS, Carneiro FA, Vieira NG, Duarte KE Vidal RO, Alekcevetch GC, Cotta MG, Verdeil JL, Montes FL, Lartaud M, Leroy T, Bellis FD, Pot D, Rodrigues GC, Carazzolle MF, Pereira GAG, Andrade AC, Marraccini, 2016. Identification of candidate genes for drought tolerance in coffee by high-throughput sequencing in the shoot apex of different Coffea arabica cultivars, BMC Plant Biology, 16: 9.

[38] P.S. Baker, 2015. Global Coffee Production and Land Use Change CABI E-UK, Bakeham Lane, Egham, Surrey, TW20 9TY, UK. 
[39] PCF, 2008. Case Study Tchibo Privat Kaffee Rarity Machare by Tchibo GMBH. PCF Pilot Project, Germany $60 \mathrm{p}$.

[40] Peter Baker, 2015. Global Coffee Production and Land Use Change

[41] S. Vijaya, Venkata Raman, S. Iniyan, Ranko Goic, 2011. A review of climate change,mitigation and adaptation. journal homepage: www.elsevier.com/locate/rser Elsivier 16 878-897

[42] Smith P, Martino D, Cai Z, Gwary D, Janzen H, Kumar P, McCarl B, Ogle S, O’Mara F, Rice C, Scholes B \& Sirotenko O, 2007. Agriculture. In Climate Change 2007: Mitigation. Contribution of Working Group III to the Fourth Assessment Report of the Intergovernmental Panel on Climate Change [B. Metz, O.R. Davidson, P.R. Bosch, R. Dave, L.A. Meyer (eds)], Cambridge University Press, Cambridge, United Kingdom and New York, NY, USA.

[43] Tubiello F, 2012. Climate change adaptation and mitigation: challenges and opportunities in the food sector. Natural Resources Management and Environment Department, FAO, Rome. Prepared for the High-level conference on world food security: the challenges of climate change and bioenergy, Rome, 3-5 June 2008.

[44] Vergara W, Rios AR, Trapido P, Malarín H, 2014. Agriculture and Future Climate in Latin America and the Caribbean: Systemic Impacts and Potential Responses, limate Change and Sustainability Division.

[45] Wrigley G, 1988. Coffee Tropical Agriculture Series, London, John Wiley and Sons, Inc., New York.

Citation: Afework Legesse, "Climate Change Effect on Coffee Yield and Quality: A Review", International Journal of Forestry and Horticulture (IJFH), vol. 5, no. 4, pp. 1-9, 2019. Available: DOI: http://dx.doi.org/ 10.20431/2454-9428.0504001

Copyright: () 2019 Authors. This is an open-access article distributed under the terms of the Creative Commons Attribution License, which permits unrestricted use, distribution, and reproduction in any medium, provided the original author and source are credited. 